UDC: $378.015 .31: 174$

DOI: https://doi.org/10.24195/2414-4665-2017-4-11

\author{
Renate Vainola, \\ Doctor of Pedagogy, professor, Department of Social Pedagogy, \\ National Pedagogical Dragomanov University, \\ 9, Pyrohova Str., Kyiv, Ukraine, \\ Svitlana Khliestova, \\ PhD (Candidate of Pedagogical Sciences), associate professor, \\ Department of Medical Biology, \\ National Pirogov Memorial Medical University of Vinnytsia, \\ 56, Pyrohova Str., Vinnytsia, Ukraine
}

\title{
CHARACTERISTICS OF THE EXPERIMENTAL WORK ON THE FORMATION OF UNIVERSITY STUDENTS' DEONTOLOGICAL CULTURE IN THE PROCESS OF SOCIO-EDUCATIONAL WORK
}

The paper presents the essence and detailed description of stages of the experimental work aimed at the formation of university students' deontological culture in the process of socio-educational work as well as the procedure of pedagogical evaluation of the levels of students' deontological culture formation. The formation of students' deontological culture is a process of gradual development of intellectual, emotional and value-related as well as operational qualities included in the structure of a future specialist's personality. Some pedagogical conditions facilitating the formation of university students' deontological culture and results of their implementation in socio-educational work of higher educational institutions have been presented in the paper. The research results have confirmed that the implementation of content and technological support and pedagogical conditions contributed to the effective implementation of structural and functional model of university students' deontological culture formation in the process of socio-educational work; therefore the goal and assumed resultthe increasing of the level of students' deontological culture formation-have been achieved.

Keywords: culture, deontology, deontological culture, the formation of students' deontological culture, socioeducational work of university students.

\section{Introduction}

At the contemporary stage of strategic reforming of Ukrainian education, some particularly topical issues arise, namely the understanding of the role of future specialists' moral and ethical becoming and reorientation of the system of socio-educational work of a higher educational institution at solving the problems of the formation and development of students' deontological culture. Relevance of the latter is determined by demanding requirements to the level of general cultural and professional development of university graduates, the necessity to train specialists with developed universal human and professional ethical values. Therefore, facilitators of socio-educational work at higher educational institutions face a number of tasks associated with substantiating the opportunities of forming students' deontological culture during extracurricular activities; developing theoretical principles, pedagogical conditions, content and technological support of the formation of students' deontological culture.

Scientific literature review demonstrates that research works on the formation of students' deontological culture in the process of socio-educational work of higher educational institutions are based on the ideas and findings of deontological theory (I. Bentam, I. Kant et al.); conceptions of professional deontology (I. Benedik, V. Horshenov, S. Husariev, O. Osaulenko, S. Slyvka, O. Tykhomyrov et al.) and cultural education (A. Arnoldov, L. Kohan, A. Losiev, O. Shevniuk, O. Shcholo- kova et al.). Also, scientists focused their attention on the issues of the formation and development of professional culture of teachers (M. Vasylieva, N. Huzii, N. Kychuk, A. Kucheriavyi, N. Losieva et al.) and medical staff (O. Krsek, M. Lisovyi, O. Uvarkina, Ya. Tsekhmister et al.). Pedagogical deontology approaches were considered in the works of H. Karakhanova, K. Kertaieva, A. Kuderina, L. Khoruzha and others. Theoretical and methodological background of socio-educational work with students of higher educational institutions were substantiated in the works of O. Bykovska, A. Kapska, S. Karpenchuk, M. Lukashevych, S. Savchenko, O. Sevastianova, H. Selevko et al. Despite a great number of works dedicated to various aspects of forming students' professional culture and ethics, the formation of deontological culture in the process of socio-educational work of a higher educational institution requires a comprehensive approach.

The paper aims to describe the stages of the experimental work aimed at the formation of university students' deontological culture in the process of socioeducational work.

\section{Research methods}

At the theoretical and methodological stage of the research, we have defined the concept of deontological culture. We consider this type of culture as a component of personality's professional culture proceeding from the definition of M. Vasylieva, who characterises deontological culture as a combination of mental and intellectual, 
emotional and value-related, professional and ethical qualities of a personality, which determine ethical and cultural significance of his/her living [2]. Accordingly, we consider the formation of students' deontological culture as a process of gradual development of intellectual, emotional and value-related as well as operational qualities included in the structure of a future specialist's personality.

We have developed a structural and functional model of students' deontological culture formation. It is considered particularly as the structural and functional one as long as its structural components and the content of the formation of university students' deontological culture are focused on solving practical problems (functions) of socioeducational work of higher educational institutions in terms of the formation of students' deontological culture [6].

We have also substantiated the components of the above-mentioned model: purpose; criteria, indexes and level of students' deontological culture formation; content and technological support (content-related components, forms and methods of socio-educational work of a higher educational institution); pedagogical conditions and the result of forming students' deontological culture. The aim of implementing the model is the formation of students' deontological culture; the result is the increase of the level of university students' deontological culture formation.

Afterwards we characterised the content-related components of socio-educational work aimed at the formation of students' deontological culture: professional component (compliance with ethic requirements, functions and professional duties); the characterological one (orientation at the formation of specific character traits: kindness, honesty, decency, altruism); moral and ethical component (focused on the formation of professional obligation and responsibility).

We have conducted experimental review of the state of the problem of students' deontological culture formation at higher educational institutions. We used questionnaire survey to identify the level of students' understanding of fundamental deontological concepts; content analysis covering higher educational institutions' work plans, curricula, programmes of the courses "Ethics" and "Ethical Issues in Medicine" to determine the proportion of academic hours allocated for studying the issue of students' deontological culture formation in the process of training. Analysis of curricula, programmes and questionnaire survey results demonstrate that the level of students' understanding of fundamental deontological concepts ("culture", "deontology" and "deontological culture") is insufficient (42.2\% among future health care workers and $48.9 \%$ among future educators). The formation of deontological culture as a task was mentioned only in $8 \%$ of the work plans; it is almost out of the scope of topics and content of socio-educational work of higher educational institutions and student groups' supervisors.

After that, it was necessary to specify criterial basis of the research for further pedagogical evaluation of the level of students' deontological culture formation. The cognitive criterion of deontological culture involves such indexes as fundamentals of professional deontology, norms and re- quirements of professional ethics, fundamentals of deontological culture. The indexes of the emotional and valuerelated criterion of students' deontological culture are realisation of deontological culture's values and their acceptance as personal ones; intention to come closer to the samples of deontological culture, positive emotions associated with professional life. The operational criterion is represented by the following indexes: adoption of behaviour corresponding to the norms and rules of deontological culture; engaging others into abiding by the norms of deontological culture.

Also, we have proposed the description of the content of the levels of university students' deontological culture formation: the adaptational level (the level of adapting to understanding and compliance with the rules and requirements of professional ethics); the reproductive one (the level of reproducing the samples of deontological behaviour according to the examples under the teacher's guidance); the constructive one (the level of understanding the content of deontological culture and attempts to design one's own model of professional and ethical behaviour), and the creative level (the level of positive emotional focus on deontological activities, which is characterised by the creative solution of ethical professional problems).

Four higher educational institutions of Ukraine were involved in the experimental study: Bogomolets National Medical University; National Pirogov Memorial Medical University, Vinnytsia; Vinnytsia State Pedagogical University named after M. Kotsiubynsky; and Pavlo Tychyna Uman State Pedagogical University. At the first stage of the experiment, 881 people were involved into the study: 856 students of I-III years of study and 25 teachers. 451 people took part in the implementation of the experimental programme: 436 students (the experimental group (EG) consisted of 204 people, and the control group (CG) included 232 people) and 15 teachers - supervisors of student groups.

In the course of the research, we developed and implemented the original methodology of pedagogical evaluation of the levels of students' deontological culture formation. It involved a set of diagnostic methods and techniques: "Unfinished Sentence" technique by N. Samsonova, "Value Orientations" methodology by M. Rokych, modified test of empathic tendencies by A. Megrabien and N. Epstein, "Professional Motivation" test by A. Krylov; narrative techniques - essays ("I'm searching for the meaning of my life", "My ideal of a professional", "Helping others as the purpose of my profession") and mini-compositions "Are ethical compromises possible in my profession?", "The significance of ethical postulates in professional activity"; methods of independent expert assessment, participant observation, analysis of educational situations and training documentation, etc.

\section{Discussion}

The generalisation of the data obtained at the summative stage of the experiment demonstrates that a large proportion of the students $(44.6 \%)$ had the indexes of deontological culture formed at the reproductive level; almost a third of the students reached only the adaptation level (33.4\%); a significantly smaller number of students 
demonstrated the constructive $(15.5 \%)$ and creative $(6.5 \%)$ levels of deontological culture formation.

An important aspect in the approbation of the structural and functional model was the implementation of pedagogical conditions for the formation of students' deontological culture, which were included into the content of the experimental work.

The experimental work involved an essential condition: planning and organisation of socio-educational work of higher educational institutions relying on basic deontological categories: the universal ones (honesty, justice, happiness, helping others, kindness) and the individual ones (dignity, conscience, honour, altruism, duty). These categories were supposed to determine the content and topics of socio-educational work with students.

The second condition was the implementation of various interactive forms of socio-educational work with university students. Analysis of interactive forms of work [1] (business games, conferences, discussions, brainstorming, etc.) allowed us to choose educational training as the most appropriate form of systematisation, updating and acquisition of students' knowledge of deontological culture issues, the formation of students' readiness for applying this knowledge practically in their future work.

The third condition - orientation of communicative interaction between socio-educational work participants at the formation of university students' deontological culture - was implemented by means of involving students and student groups' supervisors into the process of cooperative planning, organising and conducting of verbal forms of work: discussions, debates, reading conferences, round tables, as well as themed tours, meetings with experts.

The experimental work with students of the experimental group involved holding the educational training "The formation of deontological culture: the way to a professional ideal"; a series of discussions ("The importance of responsibilities in your profession", "History of formation and development of deontological culture", "The role of deontological culture in career advancement of experts involved in humane professions", etc.) and debates ("Are moral and ethical values of a doctor important in treating the sick?", "Culture or professionalism - which one is more important in doctors' and teachers' work?", "Can a doctor be unsympathetic and perform his/her duties efficiently at the same time?", "Doctors and teachers must do good without expecting gratitude - true or false?", etc.) concerning deontological subjects; and tours (e.g. to the memorial estate of M. Pyrogov).

An important part of our experimental work was holding mass events (e.g. "Health Care Day", Children's Day). We consider it reasonable to describe them in details.

The purpose of the Health Care Day was the formation of students' understanding and awareness of responsibility for their own health, and cultivating the desire to preserve their health. Taking part in the preparation and holding of this event students should realize that nowadays the issue of young people's health care is becoming particularly topical; that health is the greatest human value, which is often appreciated and cared about when it is too late.

The event involved 56 first-year students of medical universities and 52 first-year students of teacher training universities. About 400 students were engaged into this form of the work two years before its preparation and organisation. Also, the event involved about 100 pupils from lyceum schools and colleges of Vinnytsia.

The events held on Health Care Day were the following:

- game press conference "Ecology and Human Health";

- open workshop "Fundamentals of Cold Training";

- mini-football competitions;

- competition for the best sanitary bulletin;

- field assistance centre "Friendly Teaching Hospital for Young People";

- "express train" game "Forest Adventures";

- competition for the best vegetarian dish;

- funny picnic.

Socio-educational nature of this event was provided by the participation of students and adolescents in it. In this case, the students acted as teachers, assistants at all stages of the competitions, which contributed to the development of such qualities as care for others; desire to support, assist; the feeling of moral obligation and so on.

Another socio-educational event was "Children's Day". Childhood is considered to be the most important, distinctive and unique period in the development of an individual. During this very period a personality needs the most attention and protection. Modern scientists researching the issues of social and legal protection of children emphasise that the attitude to children, the understanding of their needs, interests, problems, and the state of child welfare determine the fate of each child and social development in general [4].

The initial idea in the legislative support of child rights in Ukraine is that "all children are equal from birth". According to the Article 52 of the Constitution of Ukraine, all children have equal rights regardless of their origin and race, or whether they were born in or out of wedlock [5].

We organized and held the Children's Day. The participants of this event were students and children from the orphanages "Hnizdechko" and "Maliatko". Medical students and future teachers were involved in this event as volunteers. This educational form facilitated the formation of humane attitude to orphans and children deprived of parental care. Studentsvolunteers bought some gifts at their own expense, namely: drawing blocks, paints, pencils, coloured paper, modelling clay, various sweets and toys, which were subsequently presented to the children as prizes.

The Children's Day involved the holding of the following events:

- mini-training for students-volunteers;

- interactive quiz for children "Child Rights";

- competition of posters (for older children) and drawings (for smaller children) "Happy childhood with the eyes of children"; 

heard";

- street centre for discussions "My voice must be

- "express train" game (with the following "stations": "A child has a right to information", "A child has a right to rest and leisure", "A child has a right to his/her own opinion", "A child has a right to develop his/her talents", "A child has a right to personal life");

- video lectures: "Child rights in international and domestic law"; "Give a child the right to be born"; "ABC of child rights";

- field assistance centre "A child has the right to his/her health protection" (with the participation of medical students);

- amateur video contest "I'm advertising justice".

Thus, we have implemented a number of organisational forms and methods of socio-educational work in compliance with the specific pedagogical conditions of the formation of deontological culture in university students.

At the next stage of the experimental work, we used the original methodology for pedagogical evaluation of the levels of pedagogical culture formation in the students from the control and experimental groups again; checked the effectiveness of the implemented structural and functional model of the formation of university students' deontological culture in the process of socio-educational work using mathematical statistics; identified promising trends of forming deontological culture in university students in the process of socio-educational work.

Analysis of the experimental work made it possible to find out that there was a significant difference in the levels of deontological culture formation among the students from the control and experimental groups. Analysis of experimental data demonstrated that the absolute increase at the end of the experiment was significantly different: $39.7 \%$ (81 persons) for the participants of the experimental group and $13.8 \%$ (32 persons) for participants of the control group (Table 1). The greatest total (for the creative and constructive levels) positive dynamics was observed in the indexes of cognitive $(+52 \%)$ and operational $(+38 \%)$ criteria.

Table 1.

Dynamics of the levels of students' deontological culture formation

\begin{tabular}{|l|c|c|c|c|c|c|c|c|}
\hline \multirow{4}{*}{ Levels } & \multicolumn{3}{|c|}{ At the beginning of the experiment } & \multicolumn{3}{c|}{ After the experiment } \\
\cline { 2 - 10 } & \multicolumn{2}{|c|}{$\begin{array}{c}\text { EG } \\
\text { (204 people) }\end{array}$} & \multicolumn{2}{c|}{$\begin{array}{c}\text { CG } \\
(232 \text { people) }\end{array}$} & \multicolumn{2}{c|}{$\begin{array}{c}\text { EG } \\
\text { (204 people) }\end{array}$} & \multicolumn{2}{c|}{$\begin{array}{c}\text { CG } \\
(232 \text { people) }\end{array}$} \\
\cline { 2 - 10 } & Abs. & $\%$ & Abs. & $\%$ & Abs. & $\%$ & Abs. & $\%$ \\
\hline Creative & 14 & 6.7 & 16 & 6.9 & 49 & 23.9 & 24 & 10.2 \\
\hline Constructive & 31 & 15.3 & 37 & 16.0 & 77 & 37.8 & 52 & 22.3 \\
\hline Reproductive & 93 & 45.7 & 104 & 44.8 & 63 & 31 & 113 & 48.9 \\
\hline Adaptational & 66 & 32.3 & 75 & 32.3 & 15 & 7.3 & 43 & 18.6 \\
\hline
\end{tabular}

In order to determine statistical significance of the difference between the changes in the levels of deontological culture formation among EG and KG students, we have conducted a quantitative analysis of the results obtained using the method of M. Hrabar and K. Krasnianska [3]. The results confirmed that the implementation of content and technological support and pedagogical conditions contributed to the effective implementation of structural and functional model of university students' deontological culture formation in the process of socioeducational work; therefore the goal and assumed result the increasing of the level of students' deontological culture formation - have been achieved.

\section{Conclusions}

All of the aforesaid allows us to confirm that the implementation of fundamental principles of the study can

\section{REFERENCES}

1. Vainola, R. Kh. (2008). Osobystisnyi rozvytok maibutnoho sotsialnoho pedahoha $v$ protsesi profesiinoi pidhotovky [Personality development of a future social teacher in the process of training]. S. O. Sysoieva (Ed.). Zaporizhzhia [in Ukrainian].

2. Vasylieva, M. P. (2004). Teoretychni osnovy deontolohichnoi pidhotovky pedahoha [Theoretical bases of be considered as efficient complementation to the existing practice of socio-educational work of higher educational institutions. It is also aimed at further improvement of the process of students' deontological culture formation. We are aware of the fact that this study has not solved all the problems associated with the formation of students' deontological culture. Therefore, we have identified some promising areas for further research: identifying the specific character of the formation of students' deontological culture according to their future profession; investigating the features of the formation of deontological culture in Master's students; finding out the specific character of the formation and development of deontological culture indexes during profession-oriented practical trainings.

deontological culture of a teacher]. Doctor's thesis. Kharkiv [in Ukrainian].

3. Grabar, M. I., Krasnyanskaya, K. A. (1977). Primenenie matematicheskoy statistiki v pedagogicheskikh issledovaniyakh. Neparametricheskie metody [Applying mathematical statistics to pedagogical research. Nonparametric methods]. Moscow: Pedagogika [in Russian]. 
4. Laktionova, H., Kalibaba, O., Tsiuman, T. et al. (Eds.). (2005). Prava dytyny: suchasnyi dosvid ta innovatsii [Child rights: contemporary experience and innovations]. Kyiv: Lybid [in Ukrainian].

5. Burov, S. Yu., Viitsiakh, T. V., Dubrovska, Ye. V. et al. (2007). Pravo dytyny na simiu. Treninhovyi kurs

\section{ЛІТЕРАТУРА}

1. Вайнола Р. Х. Особистісний розвиток майбутнього соціального педагога в процесі професійної підготовки : [монографія] / Р. Х. Вайнола; за ред. С. О. Сисоєвої; М-во освіти і науки України, НПУ імені М. П. Драгоманова. - Запоріжжя : ХНРБЦ, 2008. - 460 с.

2. Васильєва М. П. Теоретичні основи деонтологічної підготовки педагога : дис. ... доктора пед. наук : спец. 13.00.04 / Васильєва Марина Петрівна. Харків, 2004. - 432 с.

3. Грабарь М. И. Применение математической статистики в педагогических исследованиях. Непараметрические методы / М. И. Грабарь, К. А. Краснянская. - М. : «Педагогика», 1977. - 136 с.

dlia spetsialistiv sotsialnoi sfery [Child's right to a family. Training course for social care workers]. H. M. Laktionova (Ed.). Kyiv: Osnova-Prynt [in Ukrainian].

6. Khoruzha, L. L. (2008). Pedahohichna deontolohiia [Pedagogical deontology]. Kyiv: KMPU imeni B. D. Hrinchenka [in Ukrainian].

4. Права дитини : сучасний досвід та інновації : 3б. інформ. і метод. матеріалів / Авт.-упоряд. : Г. Лактіонова, О. Калібаба, Т. Цюман та ін. ; за заг. ред. Г. Лактіонової. - К. : Либідь, 2005. - 256 с.

5. Право дитини на сім’ю. Тренінговий курс для спеціалістів соціальної сфери / Авториупорядники : С. Ю. Буров, Т. В. Війцях, С. В. Дубровська та ін. За заг. ред. Г. М. Лактіонової. - К. : Основа-Принт, 2007. - 432 C.

6. Хоружа Л. Л. Педагогічна деонтологія : [навч-методич. посіб] / Л. Л. Хоружа. - К. : КМПУ імені Б. Д. Грінченка, 2008. - 190 с.

Ренате Хейкіївна Вайнола, доктор педагогічних наук, професор кафедри сочіальної педагогіки, Національний педагогічний університет імені М. П. Драгоманова, вул. Пирогова, 9, м. Київ, Україна,

Світлана Святославівна Хлестова, кандидат педагогічних наук, доцент кафедри медичної біології, Вінницький національний медичний університет імені М. І. Пирогова, вул. Пирогова, 56, м. Вінниия, Украӥна

\section{ХАРАКТЕРИСТИКА ЕКСПЕРИМЕНТАЛЬНОЇ РОБОТИ 3 ФОРМУВАННЯ ДЕОНТОЛОГІЧНОӤ КУЛЬТУРИ СТУДЕНТІВ ВИЩИХ НАВЧАЛЬНИХ ЗАКЛАДІВ У ПРОЦЕСІ СОЩАЛЬНО-ВИХОВНОӤ РОБОТИ}

У статті розкрито зміст та деталізовано етапи експериментальної роботи з формування деонтологічної культури студентів вищих навчальних закладів у процесі соціально-виховної роботи. Формування деонтологічної культури студентів визначено як процес поступового вироблення інтелектуальних, емоційно-ціннісних та операційних якостей в структурі особистості майбутніх фахівців. У статті визначено й теоретично обгрунтовано структурнофункціональну модель формування деонтологічної культури студентів вищих навчальних закладів у процесі соціально-виховної роботи, її мета, критерії (когнітивний, емоційно-ціннісний, операційний). Описано показники та рівні (адаптаційний, репродуктивний, конструктивний, креативний) сформованості деонтологічної культури студентів. Деталізовано змістовно-технологічне забезпечення (змістовні компоненти, форми та методи соціально-виховної роботи вищого навчального закладу). Охарактеризовано педагогічні умови формування деонтологічної культури студентів вищих навчальних закладів і результати їх упровадження в процес соціально-виховної роботи вищих навчальних закладів. Гіпотетично визначено такі умови: планування й організація соціально-виховної роботи вищого навчального закладу з урахуванням базових деонтологічних категорій; упровадження різноманітних інтерактивних форм соціально-виховної роботи зі студентами; спрямованість комунікативної взаємодії суб'єктів соціальновиховної роботи на формування деонтологічної культури студентів. Представлено методику педагогічного оцінювання рівнів сформованості деонтологічної культури студентів. Описано експериментальне впровадження комплексу форм соціально-виховної роботи: програми просвітницького тренінгу «Формування деонтологічної культури - шлях до професійного ідеалу» і тематичних днів-свят. Отримані результати дозволяють стверджувати, що впровадження обгрунтованого змістовно-технологічного забезпечення та педагогічних умов сприяли ефективній реалізації структурно-функціональної моделі формування деонтологічної культури студентів вищих навчальних закладів у процесі соціально-виховної роботи та засвідчують досягнення поставленої мети і передбачуваного результату - підвищення рівня сформованості деонтологічної культури студентів.

Ключові слова: культура, деонтологія, деонтологічна культура, формування деонтологічної культури студентів, соціально-виховна робота вищих навчальних закладів. 